Agro-Science Journal of Tropical Agriculture, Food, Environment and Extension Volume 19 Number 2 (Apr. 2020) pp. 1 - 5

ISSN 1119-7455

\title{
COMPARATIVE ANALYSIS OF THE PROFITABILITY OF SMALL AND MEDIUM SCALE CASSAVA AND PALM FRUIT PROCESSING IN ABIA STATE, NIGERIA
}

\author{
Okoronkwo F.C., *Onya S.C. and Amah J.E.
}

Department of Agricultural Economics, Michael Okpara University of Agriculture, Umudike, Nigeria

Corresponding author's email: simeononya@yahoo.com

\begin{abstract}
This study was designed to comparatively examine the profitability of small and medium scale cassava and palm fruit processing in Abia State, Nigeria. Multi-stage sampling technique was adopted in selecting 50 cassava and 50 palm fruit processors to give total respondents of 100. Simple descriptive statistics such as means and percentages, cost and returns analysis and Z-test were adopted in analyzing the data. The socioeconomic characteristics of the processors showed that middle aged persons between 25 and 54 accounted for majority (70\% and 60\%) of the respondents for cassava and palm fruit processors respectively. Also majority (60\% and 64\%) of the respondents were female. The majority of the respondents (60\% and 54\%) of the cassava and palm fruit processors had at least secondary education implying that the processing business was dominated by literates/elites. Cassava processors gained monthly net returns of $\$ 308,000$ as against 227,000 realized by palm fruit processors, indicating that cassava processing is more profitable than palm fruit processing. In view of its contribution to this paper, the following are recommended: a re-establishment of active processing firms which are income-spinning ventures; on the macro-level, government should discourage the exportation of competing products which has a multiplier effect on the operations of the firms and as such protect them from harsh competitions capable of weakening their profit performances.
\end{abstract}

Key words: profitability, palm fruit, cassava, processing, small scale, medium scale

\section{INTRODUCTION}

Small and medium enterprises (SMEs) have continued to be a popular phrase in the business world (Iorun, 2014). In Nigeria, the food processing sector is dominated by small and medium enterprises. Small and medium scale agroprocessing enterprises have played a very important role in the development of the economy of most developed and developing countries of the world, particularly in terms of employment generation especially in the rural areas, better income distribution, reduction of post-harvest food losses and increasing food availability, and as a training ground for entrepreneurs before they invest in large scale enterprises Uzoejinwa et al. (2016). The massive attention and support given to Agri-SMEs relate to the widely acclaimed fact that Agri-SMEs are major sources of employment just like the other non -agribusiness small and medium enterprises. They have a higher capacity for generating employment in Nigeria than some large scale enterprises (CBN, 1990; Taiwo et al., 2012). Cassava is one of the most important food crops of Africa. Its high resilience and adaptability to a wide range of ecological conditions has sustained its production through many generations in subSaharan Africa since it was introduced into this region in the 16th century (Adebayo et al., 2009). It is consumed in different traditional dishes varying from country to country and across communities (Adebayo, 2009). It provides increased income for farming households; increased employment opportunities; potential to target development benefits to women; potential lower food prices for consumers; competitively priced raw materials and more convenience improved traditional products Adebayo et al. (2010). Ezike et al. (2011) posited that in Nigeria cassava supplies about $75 \%$ daily calorie intake to over 50 million Nigerians in cassava growing zones. It plays a major role in country's food security as $80 \%$ of Nigerians in the rural areas eat cassava meal at least once a week and majority eat cassava products, at least once a day. It also provides one of the highest returns in value terms to effort invested (Odemero, 2015).

Cassava processing involves the transformation of raw cassava tubers into one or more finished domestic and internationally traded products by the processor. The processing is aimed at reducing the limitation of cassava roots, increase shelf-life and reduce naturally occurring cyanogens and to overcome perish ability of fresh cassava roots (Ikwuakam, 2013). Cassava and palm fruits are important, not only as a food crop but even more so as a major source of income for rural households (Davies et al., 2008). Nigeria used to be the world's 
largest producer of palm fruit (Elaeis guineensis), before the crude oil boom era and now (Ibitoye $e t$ al., 2011; Onwubuya et al., 2012). Today, Nigeria has conceded this feat to Malaysia and Indonesia which together can boast of $83 \%$ the world's total production of palm oil, while Nigeria can boast of only $1.7 \%$ of which is insufficient to meet its domestic consumption which stands at $2.7 \%$ (Okolo et al., 2019). Ibitoye (2014) reported that in Nigeria, $80 \%$ of palm fruits production comes from dispersed small holders who harvest semi-wild plants and use manual processing technique. Processing fresh fruit bunch (FFB) to extract the oil is labour intensive and involves the following stages - threshing, picking, parboiling, digestion, extraction and separation (Nwajiuba and Akinsanmi, 2003). Palm fruit gives the highest yield of oil per unit area, compared to any other oil producing plant when processed, and it produces two distinct oils; Palm fruit and Palm Kernel Oil which are of great importance in the industrial market (FAO, 2002). There are different techniques in processing palm fruit ranging from modern to traditional methods. However, the traditional method of processing is prevalent among small and medium scale processors and these small scale processors are responsible for the bulk of agro-processing in Nigeria (Olagunju, 2008). However, due to the lack of infrastructural facilities such as good roads, processing and storage equipment as well as inadequate marketing information; huge quantities of these crops (cassava and palm fruits) waste uncontrollably. An excess of 10 million tonnes of grain equivalent of food per annum conservatively estimated at over $\$ 825$ billion was reported to be lost to spoilage and wastage occasioned by the lack of post harvest management (NIFST, 2011). In view of the above, this study becomes expedient as it would provide the information needed to promote palm fruit and cassava processing enterprise and also could serve as a guide for investors in the venture as well as for policy makers.

This paper aimed to comparatively examine the profitability of small and medium scale cassava and palm fruit processing enterprises in Abia State while focusing exclusively on: examining the socioeconomic characteristics of the cassava and palm fruit processors; ascertaining the cost and returns associated with cassava and palm fruit processing and identifying constraints affecting the profitability of cassava and palm fruit processing business in the study area.

\section{MATERIALS AND METHODS}

The study was carried out in Abia State. The State lies between longitude $04^{\circ} 45^{\prime}$ and $06^{\circ} 07^{\prime}$ North and Latitude $07^{\circ} 00^{\prime}$ and $08^{\circ} 10^{\prime}$ East. It is situated in the south-east geo-political zone of Nigeria and is bounded by Imo State on the West, Ebonyi and Enugu States on the North, Cross Rivers and
Akwa-Ibom States on the East and Rivers State on the South. The State has a population density of 580 persons per square kilometer and a population of 2,833,999 persons (NPC, 2006). The climate of the State is a tropical one and usually humid all year round. The major occupation of the people is farming and the major crops grown are Maize, yam, cassava, rice, vegetable, etc. Livestock kept include, goat, sheep, Pigs, etc. Plantain, palm fruit, cocoa and rubber are some of the cash crops produced by the people. Multi-stage sampling technique was adopted for this study. The first stage was the selection of two agricultural zones (Umuahia and Aba zones) out of the three agricultural zones in the state. The second stage involved the random selection of one local government each (Ikwuano and Isiala Ngwa South) from the selected agricultural zones. In the third stage, five villages were selected while the last stage involved the random selection of five cassava and palm fruit processors respectively from the list of cassava and palm fruit processors from each village giving a total of 50 cassava and 50 palm fruit processors. Primary data were used for the study. Data collected were analyzed using simple descriptive statistics such as mean and percentages, costs and returns analysis and Z-test models.

\section{Model Specification}

Profit- $\pi$ TR-(TFC+TVC)

Where $\pi$-profit TR-Total revenue(comprises of Palm oil, cracked and un-cracked Palm kernel and sludge for palm fruit processors and garri, fufu, flour and starch for cassava processors) TFC-Total fixed cost (depreciation on fixed assets, interest on borrowed capital and rent) TVC-Total variable cost (transport, labour (family and hired), firewood, diesel, water, electricity palm fruits and cassava). The $\mathrm{Z}$ - test is given as:

$$
\text { Zcal. }=\frac{\bar{X} 1-\bar{X} 2}{\frac{\sqrt{s_{1}^{2}} \bar{X} 1}{n^{1}}+\frac{s_{2}^{2} \bar{X} 2}{n^{2}}} ;
$$

where, $\bar{X}_{1}$ is mean net income from cassava processors, $\bar{X}_{2}$ is mean net income from palm fruit processors, $S_{1}^{2} \bar{X}_{1}$ is Variance of net income from cassava processors, $S_{1}^{2} \bar{X}_{2}$, variance of net income from palm fruit processors, $\mathrm{n}^{1}$ is number of cassava processors, and $\mathrm{n}^{2}$ is number of palm fruit processors.

\section{RESULTS AND DISCUSSION \\ Socioeconomic Characteristics of Cassava and Palm fruit Processors}

The socioeconomic characteristics of cassava and palm fruit processors is presented in Table 1.The distribution of the respondents by age showed that majority (82\% and $70 \%$ ) of the cassava and palm fruit processors respectively were between the age of 25 and 54 years while $18 \%$ and $30 \%$ were between the ages of 55 and 74 years. This implies that cassava 
Table1: Socio-economic characteristics of the processors

\begin{tabular}{|c|c|c|c|c|}
\hline \multirow{2}{*}{ Age } & \multicolumn{2}{|c|}{$\begin{array}{l}\text { Cassava } \\
\text { processors }\end{array}$} & \multicolumn{2}{|c|}{$\begin{array}{l}\text { Palm fruit } \\
\text { processors }\end{array}$} \\
\hline & $\begin{array}{l}\text { Freq- } \\
\text { uency }\end{array}$ & $\begin{array}{l}\text { Percent- } \\
\text { age }(\%)\end{array}$ & $\begin{array}{l}\text { Freq- } \\
\text { uency }\end{array}$ & $\begin{array}{l}\text { Percent- } \\
\text { age }(\%)\end{array}$ \\
\hline $25-34$ & 6 & 12 & 5 & 10 \\
\hline $35-44$ & 15 & 30 & 12 & 24 \\
\hline $45-54$ & 20 & 40 & 18 & 36 \\
\hline $55-64$ & 6 & 12 & 10 & 20 \\
\hline $65-74$ & 3 & 6 & 5 & 10 \\
\hline Total & 50 & 100 & 50 & 100 \\
\hline \multicolumn{5}{|l|}{ Gender } \\
\hline Males & 20 & 40 & 18 & 36 \\
\hline Females & 30 & 60 & 32 & 64 \\
\hline Total & 50 & 100 & 50 & 100 \\
\hline \multicolumn{5}{|l|}{ Household size } \\
\hline $1-4$ & 30 & 60 & 33 & 66 \\
\hline $5-8$ & 15 & 30 & 10 & 20 \\
\hline $9-11$ & 5 & 10 & 7 & 14 \\
\hline Total & 50 & 100 & 50 & 100 \\
\hline \multicolumn{5}{|l|}{ Marital status } \\
\hline Married & 25 & 50 & 30 & 60 \\
\hline Single & 15 & 30 & 10 & 20 \\
\hline Divorced & 5 & 10 & 5 & 10 \\
\hline Widowed & 5 & 10 & 5 & 10 \\
\hline Total & 50 & 100 & 50 & 100 \\
\hline \multicolumn{5}{|l|}{ Level of education } \\
\hline No formal education & 10 & 20 & 9 & 18 \\
\hline Primary education & 10 & 20 & 14 & 28 \\
\hline Secondary education & 25 & 50 & 23 & 46 \\
\hline Tertiary education & 5 & 10 & 4 & 8 \\
\hline Total & 50 & 100 & 50 & 100 \\
\hline
\end{tabular}

Source: Field Survey, 2016

and palm fruit processing are mostly done by young and middle aged people. This may be as a result of the energy and technical know-how needed to operate most of the processing machines. The gender distribution of the processors showed that $40 \%$ and $36 \%$ of the cassava and palm fruit processors were males while $60 \%$ and $64 \%$ were females. This implies that cassava and palm fruit processing in the area are dominated by the female. The distribution of respondents based on household size showed that majority $(60 \%$ and $66 \%)$ of the cassava and palm fruit processors, respectively had household size of between 1 and 4 persons, $30 \%$ and $20 \%$ had household size of between 5 and 8 persons, while $10 \%$ and $14 \%$ of the cassava and palm fruit processors had household size of between 9 and 11 persons. The result implies that cassava and palm fruit processors in the study area have a small household size and this could affect the supply of labour needed in their enterprises. The distribution of the respondents based on their marital status showed that majority (50\% and 60\%) of the cassava and palm fruit processors were married, while $50 \%$ and $40 \%$ of the cassava and palm fruit processor respectively were either single divorced or widowed. This implies that cassava and palm fruit processing are dominated by married people. Given the income generating capacity of the cassava and palm fruit processing enterprises and the need to meet marital responsibility, married people tend venture into the enterprises than the unmarried people. The majority $(60 \%$ and $54 \%)$ of the cassava and palm fruit processors had at least secondary education implying that the processing business was dominated by literates/elites. The educational level of the processors will go a long way to helping them embrace new technology needed to help them improve the income.

\section{Cost and Return Analysis of Cassava and Palm fruit Processors}

The cost and return analysis of cassava and palm fruit processors is presented in Table 2. The cost and return analysis of the cassava and palm fruit processors showed that both enterprises are profitable given their positive total revenue, gross margins and net returns. However, cassava processors gained monthly net returns of $\$ 308,000$ as against $\$ 227,000$ realized by palm fruit processors indicating that cassava processing is more profitable than palm fruit processing. Also the return on investment was $\$ 2.22$ and $\$ 1.88$ for cassava and palm fruit processors implying that for every $\$ 1$ invested $\$ 1.22$ and 88kobo was made in cassava and palm fruit processing respectively. The high return on investment of cassava processing was as a result of the low cost of processing cassava relative to that of palm fruit and also cassava is a staple with all round demand and market. This corroborates the finding of Onya et al. (2016) who found a return on investment of $\$ 2.36$ for cassava processing and (Olagunju, 2008; Onoja and Ogali, 2014) who found a return on investment of $\$ 1.29$ and $\$ 1.72$ for palm fruit processing in their respective studies. Also, the gross ratio was 0.45 and 0.53 for cassava and palm fruit processing respectively which means that the total cost of processing is made up of $45 \%$ and $53 \%$ for cassava and palm fruit processing which make cassava processing more cost effective than palm fruit processing. It is expected that with increased capital, improved technology and skilled labour, this ratio would increase.

Table 2. Cost and returns analysis of cassava and palm fruit processors

\begin{tabular}{|c|c|c|}
\hline Item (monthly expenses) & $\begin{array}{l}\text { Cassava } \\
\text { processors }\end{array}$ & $\begin{array}{l}\text { Palm fruit } \\
\text { processors }\end{array}$ \\
\hline 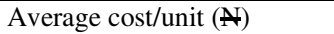 & 1,800 & 1,250 \\
\hline Average selling cost/unit ( & 3,500 & 2,700 \\
\hline Average variable cost ( & 154,000 & 143,000 \\
\hline Average fixed cost ( $)$ & 98,000 & 115,000 \\
\hline Average total cost $(N)$ & 252,000 & 258,000 \\
\hline Average total revenue ( $)$ & 560,000 & 485,000 \\
\hline 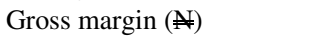 & 504,000 & 342,000 \\
\hline Net returns $(\mathbb{N})$ & 308,000 & 227,000 \\
\hline Return on investment & 2.22 & 1.88 \\
\hline Profit margin & 0.55 & 0.47 \\
\hline Gross ratio & 0.45 & 0.53 \\
\hline
\end{tabular}

Source: Field Survey, 2016 
Table 3: The z-test value between the estimated net income from cassava and palm fruit processing in the study area

\begin{tabular}{lllll}
\hline Variable & Observation & Mean & Std. Err & Std. Dev \\
\hline Cassava Processors & 50 & 308,000 & 15747.51 & 105637.5 \\
Palm fruit Processors & 50 & 227,000 & 10996.12 & 73764.21 \\
\hline Source: Field Survey, 2016. ***Significant at 1\% level &
\end{tabular}

Table 4: Problems militating against the effectiveness of cassava and palm fruit processing in the study area

\begin{tabular}{|c|c|c|c|c|c|c|}
\hline \multirow[t]{2}{*}{ Constraint } & \multicolumn{3}{|c|}{ Cassava processors } & \multicolumn{3}{|c|}{ Palm fruit processors } \\
\hline & Frequency* & Percentage & Ranking & Frequency* & Percentage & Ranking \\
\hline Inadequate capital/finance & 33 & 66.00 & $3^{\text {rd }}$ & 34 & 68.00 & $4^{\text {th }}$ \\
\hline Poor access to credit & 9 & 18.00 & $8^{\text {th }}$ & 10 & 20.00 & $8^{\text {th }}$ \\
\hline Unstable price of product & 36 & 72.00 & $2^{\text {nd }}$ & 18 & 36.00 & $7^{\text {th }}$ \\
\hline High charges from the government & 5 & 10.00 & $9^{\text {th }}$ & 8 & 16.00 & $9^{\text {th }}$ \\
\hline High cost of processing machine & 30 & 60.00 & $4^{\text {th }}$ & 44 & 88.00 & $1^{\text {st }}$ \\
\hline Lack of storage facilities & 41 & 82.00 & $1^{\text {st }}$ & 37 & 74.00 & $3^{\text {rd }}$ \\
\hline High cost of transportation & 20 & 40.00 & $5^{\text {th }}$ & 22 & 44.00 & $6^{\text {th }}$ \\
\hline Poor road network & 12 & 24.00 & $7^{\text {th }}$ & 30 & 60.00 & $5^{\text {th }}$ \\
\hline Lack of electricity to reduce dependence on firewood & 19 & 38.00 & $6^{\text {th }}$ & 39 & 78.00 & $2^{\text {nd }}$ \\
\hline
\end{tabular}

Source: Field Survey, 2016, Multiple responses*

Test of Significant Difference between the Estimated Net Income from Cassava Processing and Palm Fruit Processing in the Study Area

The test of significant difference between the estimated net income from cassava processing and palm fruit processing is presented in Table 3. The data show that the mean estimated net income for cassava processing was 308,000 and that of palm fruit processing was 227,000 . The mean difference between cassava processing and palm fruit processing was 81,000 . The value of $Z$ cal. was $5.093 * * *$ and $\mathrm{Z}$ tab. $=2.423 * * *$. Since $\mathrm{Z}$ cal. $>\mathrm{Z}$ tab., the null hypothesis which stated no significant difference between estimated net return generated from cassava processing and palm fruit processing is hereby rejected and the alternate accepted. Hence, there is a significant difference between the estimated net return of cassava processing and palm fruit processing. This is basically attributable to bad road network which characterizes the area.

The problem of high cost of processing machines was identified by the respondents followed by lack of electricity to reduce dependence on firewood. Regular dependence on processors of palm fruit on fuel wood as a major energy source portends serious environmental hazards such as desertification. Lack of storage facilities lead to spoilage of processed product and as such the processor can only process the one his storage capacity can hold.

\section{Problems Militating Against the Effectiveness of Cassava and Palm Fruit Processing}

The problems militating against the effectiveness of cassava and palm fruit processing in the study area is presented (Table 4). The data show that lack of storage facilities (82\%), unstable price of product (72\%); price instability reduces the uncertainty of the business and reduces the confidence of the processor, inadequate capital $(66 \%)$; inadequate capital will hinder the processors from procuring modern processing plant and expanding their business capacity, high cost of processing machine $(60 \%)$ and high cost of transportation $(40 \%)$ were the major problems constraining the effective and profitable processing of cassava in the study area. Also high cost of processing machine $(88 \%)$, lack of electricity to reduce dependence on firewood (78\%), lack of storage facilities $(74 \%)$, inadequate capital/finance $(68 \%)$ poor road network $(60 \%)$ and high cost of transportation (44\%) were the major problems constraining the effective profitability of palm fruit processing in the area. For the poor road network and high transportation cost, most vehicles charge the farmers very high amounts since they ply bad roads in the area as they haul the palm products from the processing centres to the markets. This supports of Obasi et al. (2014) and Obasi and Kalu (2015) that transportation is the most critical factor affecting marketers and their performance in many developing economies.

\section{CONCLUSION AND RECOMMENDATIONS}

This study has been able to comparatively analyse the profitability of cassava and palm fruit processing enterprises while looking at the viability of the businesses as well as the challenges hindering it in Abia state. It was found that the both business are viable and portend a very useful and reliable means of making profits and raising household incomes in the study area though there are still some major challenges with lack of storage facilities, unstable price of product, inadequate capital/finance, high cost of processing machine, lack of electricity to reduce dependence on firewood, poor road network and high cost of transportation constraining the profitability of cassava and palm fruit processing in the study area. The major findings of the study were that cassava processing was more profitable than palm fruit processing and that there is significant difference between the estimated net return of cassava processing and palm fruit processing which entails encouraging farmers who are in these businesses to solve their problems will go a long way in solving the problem of poverty and looming food crises in Nigeria. The study revealed some of these major problems being faced by cassava and palm fruit 
processors in the area. Solving these problems will be a way forward in the drive for food security and poverty alleviation. It is recommended that the state and federal governments gear up efforts to provide basic infrastructure such as electricity and good, motor-able roads so that the efficiency of processing and marketing of cassava and palm fruit products can be guaranteed. The issue of electricity supply will reduce dependency on fuel wood, thus stemming environmental degradation in the area.

The state and federal government should also use their agencies and parastatals to subsidize inputs, especially processing machines. Processors revenue base can be more enhanced if multipurpose automatic machine could be supplied by government at subsidized rate to reduce extraction cost. This will boost their output and reduce the cost of production, processing and marketing.

Farmers should be encouraged by banks and agricultural extension agents in the state to form cassava and palm fruit processing cooperatives so that they may benefit from the banks' loan facilities or government agencies' loans. This can solve the problem of lack of capital.

\section{REFERENCES}

Adebayo K. (2009). Dynamics of the technology adoption process in rural-based cassava processing systems in Southwest Nigeria. Int. J. Agric. Econs. Rural Dev., 2 (1), 15-25

Adebayo K., Lamboll R.I. and Westby A. (2009). Contextualizing environmental, social and behavioral issues in the cassava post-harvest system in Africa. In: Veena B. and Charles S. (eds.), Anthropologist Today: Trends and Scope of Human Ecology (pp. 137-146). India: Published by Kamla-Raj Enterprises

Adebayo K., Abayomi L., Abass A. et al. (2010). Sustainable inclusion of smallholders in the emerging high quality cassava flour value chains in Africa: challenges for Agricultural Extension Services. $J$. Agric. Ext., 14 (1), 1-10

CBN (1990). First Annual Monetary Policy and Measurement. Central Bank of Nigeria (CBN), Macmillan Publishing Company, London

Davies R.M., Olatunji M.O. and Burubai W. (2008). A survey of cassava processing machinery in Oyo State. World J. Agric. Sci., 4 (3), 337-340

Ezike K.N.N., Nwibo S.U. and Odoh N.E. (2011). Cassava production, commercialization and value addition. Proc. of the 25th National Conference of Farm Management Association of Nigeria, held at the Federal College of Agriculture, Akure, Nigeria, 173

FAO (2002). Small scale palm fruit processing in Africa. FAO Agricultural Services Bulletin, 148. ISSN 10101365. Rome, Italy

Ibitoye O.O., Akinsorotan A.O., Meludu N.T. and Ibitoye B.O. (2011). Factors affecting palm fruit production in Ondo State of Nigeria. J. Agric. Soc. Res., 11 (1), 97-105

Ibitoye S.J. (2014). Economic analysis of palm oil marketing in Dekina Local Government Area of Kogi State, Nigeria. Asian J. Soc. Sci., Arts Humanities, 2 (1), 1-19
Ikwuakam O. T. (2013). Determinants of socio-economic status of cassava processing entrepreneurs in SouthEastern Nigeria. J. Agric. Vet. Sci., 5 (2), 140-150

Iorun I.J. (2014). Evaluation of survival strategies of small and medium enterprises in Benue State, Nigeria. Int. J. Acad. Res. Accounting, Finance Manage. Sci., 4 (2), 255-263

NIFST (2011). Value addition to Nigerian food raw materials: a panacea for national food security and poverty reduction. Communiqué of the Nigerian Institute of Food Science \& Technology, 35th General Meeting and Scientific Conference, Makurdi, Benue State, 10th - 14th October, 2011

NPC (2006). Nigerian Census Figures. Nigerian Population Commission (NPC), Abuja

Nwajiuba C. and Akinsanmi A. (2003). Implications of improved oil palm (Elaeis guineensis) fruit processing technologies for labour and income among rural households in Imo State, Nigeria. Deutscher Tropentag 8-10, 2003. Goettingen, Germany

Obasi I.O. and Kalu M. (2015). Profitability and efficiency of palm oil marketing in Arochukwu Local Government Area of Abia State Nigeria. Res. J. Agric. Environ. Manage., 4 (9), 438-444

Obasi I.O., Igwe K.C. and Ogbonna C.E. (2014). Economics of palm oil marketing in Bende Local Government Area of Abia State, Nigeria. Advanced J. Agric. Res., 2 (7), 104-108

Odemero A.F. (2015). Impact of cassava value chain intensification intervention on Nigerian economy: evidence from Delta State, Nigeria. Turkish J. Agric. Natural Sci., 2 (1), 18-25

Okolo C.C., Okolo E.C., Nnadi A.L., Obikwelu F.E., Obalum S.E. and Igwe C.A. (2019). The oil palm (Elaeis guineensis Jacq): nature's ecological endowment to Eastern Nigeria. Agro-Science, 18 (3), 48-57

Olagunju F.I. (2008). Economics of palm fruit processing in South Western Nigeria. Int. J. Agric. Res., 1 (2), 69-77

Onoja A.O. and Ogali T.U. (2014). Economic survey of palm fruit products' processing and marketing in Kogi State, Nigeria. Consilience: The J. Sustainable Dev., 13 (1), 336-346

Onwubuya E.A., Ajani E.N. and Nwalieji H. (2012). Assessment of Palm fruit Production and Processing Among Rural Women in Enugu North Agricultural Zone of Enugu State, Nigeria. Int. J. Agric. Sci., 2 (12), 322-329

Onya S.C., Oriala S.E., Ejiba I.V. and Okoronkwo, F.C. (2016). Market participation and value chain of cassava farmers in Abia State, Nigeria. J. Scientific Res. Reports, 12 (1), 1-11

Taiwo M.A., Ayodeji A.M. and Yusuf B.A. (2012). Impact of small and medium enterprises on economic growth and development. Am. J. Business Manage., 1 (1), 18-22

Uzoejinwa B.B., Ani A. O., Abada U.C., Ugwuishiwu B.O., Ohagwu C.J. and Nwakaire J.N. (2016). Smallscale food processing enterprises: measures for national development and addressing food security challenges in Nigeria. Int. J. Scientific Technical Res. Engineering, 1 (5), 72-82 